\title{
HUBUNGAN KELAS NYHA DENGAN FRAKSI EJEKSI PADA PASIEN GAGAL JANTUNG KRONIK DI BLU/RSUP PROF. DR. R.D. KANDOU MANADO
}

\author{
${ }^{1}$ Patricia Ratna Sari \\ ${ }^{2}$ Starry H. Rampengan \\ ${ }^{2}$ Agnes L. Panda \\ ${ }^{1}$ Kandidat skripsi Fakultas Kedokteran Universitas Sam Ratulangi Manado \\ ${ }^{2}$ Bagian Kardiologi dan Kedokteran Vaskular Fakultas Kedokteran Universitas Sam \\ Ratulangi Manado \\ Email: Patricia.cia92@yahoo.com
}

\begin{abstract}
The functional status of patients with chronic heart failure (CHF) has been standardized by the classification of NYHA [New York Heart Association] class I-IV. One of the parameters to assess the ability of the heart function is the ejection fraction (LVEF) were assessed using echocardiography parameters. The purpose of this study was to determine the relationship of NYHA class with ejection fraction in patients with chronic heart failure in the BLU/Prof. Dr. R. D. Kandou Manado. Methodology: This research method is analytic cross sectional study approach. The sample was CHF patients in BLU/Prof. Dr. R. D. Manado Kandou 30 people held during November-December 2012. Results: The distribution of patients according to NYHA class most are in NYHA II (43\%), while the lowest are in NYHA IV (7\%). Distribution according to the ejection fraction is at most $30-39 \%$ LVEF is 12 and there are at least LVEF $<30 \%$, is 6 people. The results obtained using the Spearman test $(\mathrm{p}=0.177)$, indicating that there was no statistically significant association between NYHA class with ejection fraction in patients with chronic heart failure in the BLU/Prof. Dr. R. D. Kandou Manado.Conclusion: No significant relationship was found between NYHA class with ejection fraction.
\end{abstract}

Keywords: Chronic Heart Failure, ejection fraction, NYHA class

\begin{abstract}
Abstrak: Status fungsional penderita gagal jantung kronik (GJK) ini telah dibakukan berdasarkan klasifikasi NYHA [New York Heart Association] kelas I-IV. Salah satu parameter untuk menilai kemampuan fungsi jantung adalah fraksi ejeksi (LVEF) yang dinilai menggunakan parameter ekokardiografi. Tujuan penelitian ini adalah untuk mengetahui hubungan kelas NYHA dengan fraksi ejeksi pada penderita gagal jantung kronik di BLU/RSUP Prof. Dr. R. D. Kandou Manado. Metodologi: Metode penelitian ini bersifat analitik dengan pendekatan studi cross sectional. Sampel penelitian ini adalah pasien GJK di BLU/RSUP. Prof. Dr. R. D. Kandou Manado sebanyak 30 orang yang berlangsung selama bulan November - Desember 2012. Hasil : Distribusi pasien GJK menurut kelas NYHA terbanyak berada pada NYHA II (43\%), sedangkan yang paling rendah berada pada NYHA IV (7\%). Distribusi menurut Fraksi Ejeksi terbanyak berada pada LVEF 30-39 $\%$ yaitu 12 orang dan paling rendah terdapat pada LVEF $<30 \%$ yaitu 6 orang. Hasil penelitian ini menggunakan uji Spearman diperoleh $(p=0,177)$, menunjukkan bahwa secara statistik tidak terdapat hubungan bermakna antara NYHA kelas dengan fraksi ejeksi pada pasien gagal jantung
\end{abstract}


kronik di BLU/RSUP Prof. Dr. R. D. Kandou Manado. Kesimpulan:Tidak ditemukan hubungan yang signifikan antara kelas NYHA dengan fraksi ejeksi.

Kata kunci : Fraksi ejeksI, Gagal Jantung Kronik, Kelas NYHA [New York Heart Association]

Gagal jantung adalah sindrom klinis (sekumpulan tanda dan gejala), ditandai oleh sesak nafas yang dapat timbul dalam keadaan istirahat atau saat aktivitas dan disebabkan oleh kelainan struktur atau fungsi jantung dengan menurunnya curah jantung secara tiba-tiba yang dapat menyebabkan penurunan tekanan darah tanpa disertai edema perifer. ${ }^{1}$ Gagal jantung kronik adalah sindrom atau kumpulan gejala dimana ketidakmampuan jantung untuk memompa darah yang mengandung oksigen ke berbagai jaringan penting pada tingkat tekanan pengisian ventrikel yang memicu efek progresif dan meluas yang mempengaruhi struktur dan fungsi jantung dan organ-organ lain di seluruh tubuh. ${ }^{2}$ Faktor resiko gagal jantung sangat bervariasi tergantung dari populasi yang diteliti. Di negara-negara berkembang antara lain berupa faktor resiko berupa penyakit katup jantung, kekurangan gizi, dan infeksi (trypanosomiasis) menjadi faktor resiko gagal jantung kronik. Di negara maju, antara lain penyakit jantung koroner, diabetes mellitus, dan hipertensi merupakan faktor utama yang berperan terhadap peningkatan resiko GJK. ${ }^{3}$

Sekitar 3-20 per 1000 orang pada populasi mengalami gagal jantung, prevalensinya meningkat seiring pertambahan usia (100 per 1000 orang pada usia di atas 65 tahun), pada angka ini akan meningkat karena peningkatan usia, populasi, dan perbaikan ketahanan hidup setelah infark miokard akut. ${ }^{4}$ Lebih dari 5 juta orang Amerika Serikat adalah penderita gagal jantung dan 550.000 pasien terdiagnosa menderita gagal jantung setiap tahun. Di Inggris, sekitar 100.000 penderita gagal jantung dirawat di rumah sakit pada usia diatas 55 tahun. ${ }^{5}$ Di Indonesia sendiri belum ada angka pasti tentang prevalensi penyakit gagal jantung, di RS Jantung Harapan Kita, setiap hari ada sekitar 400-500 pasien berobat jalan dan sekitar $65 \%$ adalah pasien gagal jantung. ${ }^{6}$

Banyak pasien dengan gagal jantung stadium lanjut tidak menunjukkan tanda-tanda fisik dari kongesti paru, karena perubahan kronis yang terjadi pada pembuluh darah paru. Penderita GJK yang lain hanya menunjukkan gejala berupa dsypnea dan mudah capek. Status fungsional penderita telah dibakukan sesuai dengan sistem klasifikasi NYHA [New York Heart Association] kelas I-IV, sebuah sistem yang memungkinkan dokter untuk membandingkan strata fungsional dalam populasi pasien dengan gagal jantung dan juga berguna dalam menentukan penatalaksanaan dan prognostik kelainan yang dialami. ${ }^{7}$

Salah satu parameter untuk menilai kemampuan fungsi jantung adalah fraksi ejeksi (EF). Fraksi ejeksi dinilai menggunakan parameter ekokardiografi dengan nilai normal 55\%, dan $<40 \%$ dianggap sudah difungsi ventrikel kiri. ${ }^{4,8}$ Fraksi ejeksi ini mewakili isi sekuncup sebagai presentase dari volume akhir diastolik ventrikel kiri, dimana terdapat dua metode yang diterima secara umum untuk mengukur fraksi ejeksi, yaitu teknik volumentrik dan rekaman M-mode. ACC/AHA (American College of Cardiology/American Heart Association) tidak pernah mengklasifikasikan tingkat keparahan gagal jantung berdasarkan fraksi ejeksi namun disebutkan tentang gagal jantung sistolik (FE <50\%) dan gagal jantung diastolik (FE >50\%), hanya studi-studi dengan sampel pasien gagal jantung yang mengelompokkannya berdasarkan fraksi ejeksi, misalnya studi SOLVD, PROMISE, GESICA yang memakai batasan fraksi ejeksi $<35 \%$ untuk gagal jantung yang berat (NYHA III-IV), namun ada juga studi yang memakai batasan fraksi ejeksi $<40 \%$ untuk yang berat. ${ }^{9-11}$

Berdasarkan uraian data diatas, mendorong penulis untuk melakukan penelitian apakah terdapat hubungan kelas NYHA dengan fraksi ejeksi pada penderita gagal jantung kronik di BLU/RSUP.Prof.Dr.R.D.Kandou Manado.

\section{METODE PENELITIAN}

Bentuk penelitian ini adalah bersifat analitik dengan pendekatan cross sectional, yaitu mengumpulkan data rekam medis dari status pasien gagal jantung kronik di BLU/RSUP Prof. Dr. R. D. 
Kandou Manado dan menentukan hubungan antar kelas NYHA dengan fraksi ejeksi. Penelitian ini dilakukan di BLU/RSUP Prof. Dr. R. D. Kandou Manado, dengan rentang waktu sekitar bulan November 2012 sampai dengan Desember 2012. Populasi penelitian ini adalah Populasi adalah seluruh pasien gagal jantung kronik yang berobat di BLU/RSUP Prof. Dr. R. D. Kandou Manado.

Besar sampel diperoleh dengan menggunakan rumus :

$n=\left[\frac{\left(z_{\alpha}+z_{\beta}\right)}{0,5 \ln [(1+r) /(1-r)]}\right]^{2}+3$

Keterangan ; $\mathrm{n}$ : besar sampel

$\mathrm{Z} \alpha$ : deviat baku alfa

$\mathrm{Z} \beta$ : deviat baku beta

r $\quad$ : korelasi

Sampel diambil berdasarkan kriteria inklusi yaitu penderita GJK yang bersedia dijadikan sebagai subjek penelitian, penderita GJK dengan etiologi penyakit jantung iskemik, penyakit jantung koroner, dan sindrom koroner akut dan LVEF $\leq 50 \%$. Pada kriteria eksklusi yaitu penderita GJK yang tidak bersedia dijadikan sebagai subjek penelitian, penyakit jantung katup, wanita hamil. riwayat atau gejala hipertiroid, penyakit atau kelainan paru seperti tumor paru, TB paru. Variable penelitian Umur, jenis kelamin, faktor penyebab gagal jantung kronik, gagal jantung menurut klasifikasi New York Heart Associaton (NYHA) dan fraksi ejeksi

Pengambilan sampel ini dilakukan dengan cara : 1.) mengumpulkan data kasus secara analitik dengan menggunakan data primer berupa pemeriksaan secara langsung yaitu menentukan pasien gagal jantung kronik dengan klasifikasi kelas NYHA, melakukan permeriksaan laboratorium berupa pemeriksaan darah lengkap, kadar kolesterol, pemeriksaan fungsi hati, pemeriksaan fungsi ginjal, pemeriksaan elektrolit, rontgen, EKG dan melakukan pemeriksaan echocardiografi untuk menentukan fraksi ejeksi dengan menggunakan Esaote my Lab 50. 2.) mengolah data berdasarkan variabel penelitian dan disajikan dengan cara menyusunnya dalam bentuk tabel, grafik dan persentase. 4.) melakukan konsultasi dengan dosen pembimbing. 5.) penyusunan dan pengetikan naskah akhir. 6.) menelaah kembali naskah.

\section{HASIL PENELITIAN}

A. Distribusi frekuensi pasien dengan gagal jantung kronik di BLU RSUP Prof. Dr. R. D. Kandou Manado Periode November - Desember 2012.

1. Distribusi pasien berdasarkan jenis kelamin

Pada penelitian ini menunjukan dimana persentase pasien dengan gagal jantung kronik laki-laki (73\%) lebih banyak dibandingkan dengan pasien perempuan (27\%). (gambar 1) 


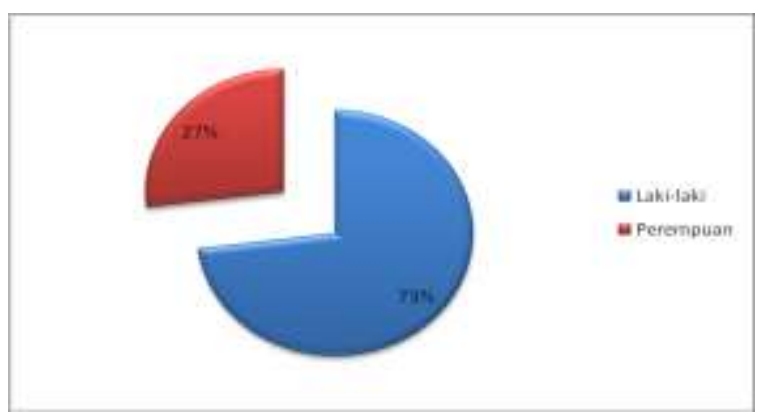

Gambar 1. Persentase penderita gagal jantung kronik menurut jenis kelamin

2. Distribusi pasien gagal jantung kronik menurut usia

Hasil penelitian menunjukan bahwa pasien dengan gagal jantung kronik yang datang untuk mendapatkan pelayanan di BLU/RSUP Prof. Dr. R. D. Kandou Manado terbanyak berada pada kelompok usia 60-69 tahun (40\%). Gambar 2.

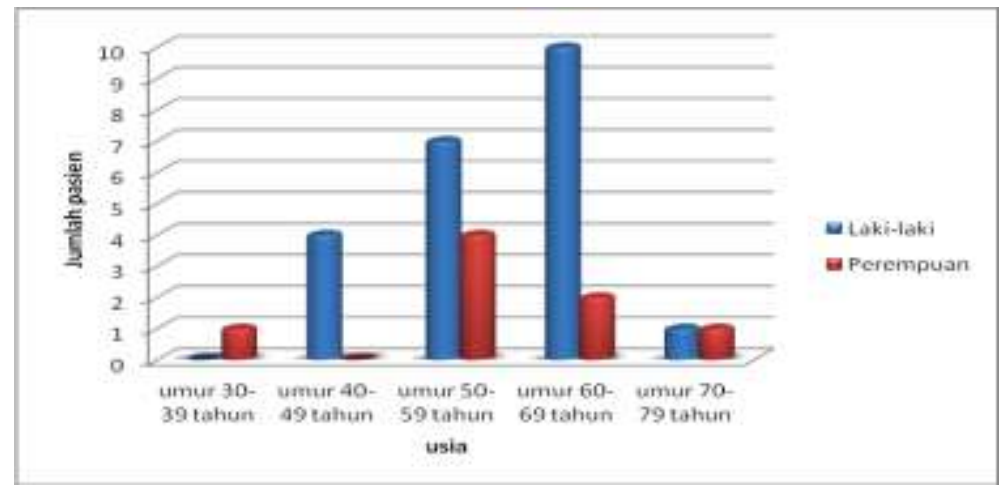

Gambar 2. Grafik penderita gagal jantung kronik menurut usia dan jenis kelamin.

3. Distribusi pasien gagal jantung kronik menurut kelas NYHA

Hasil penelitian menunjukan bahwa pasien dengan gagal jantung kronik yang datang untuk mendapatkan pelayanan di BLU/RSUP Prof. Dr. R. D. Kandou Manado terbanyak berada pada fungsional kelas II (43\%), sedangkan yang paling rendah berada pada fungsional kelas IV (7\%). (gambar 2) 


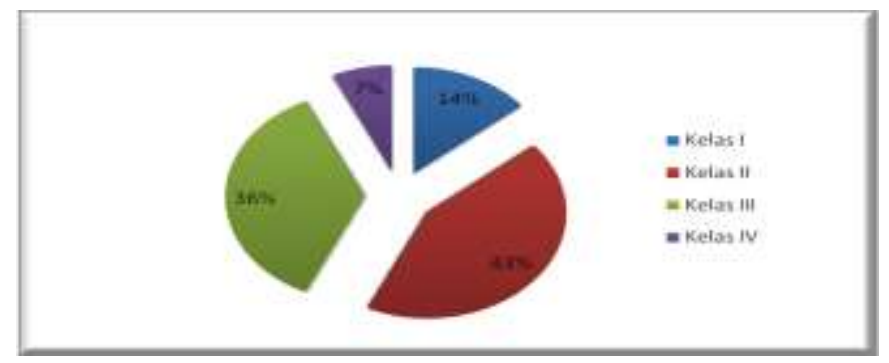

Gambar 3. Persentase penderita gagal jantung kronik menurut NYHA

4. Distribusi pasien gagal jantung kronik menurut Fraksi Ejeksi

Pada hasil penelitian menunjukan bahwa sebagian besar penderita gagal jantung kronik di BLU/RSUP Prof. Dr. R. D. Kandou Manado terbanyak berada pada fraksi ejeksi 30-39 \% adalah 12 orang, sedangkan yang paling rendah terdapat pada fraksi ejeksi $<30 \%$ adalah 6 orang. (gambar 3 )

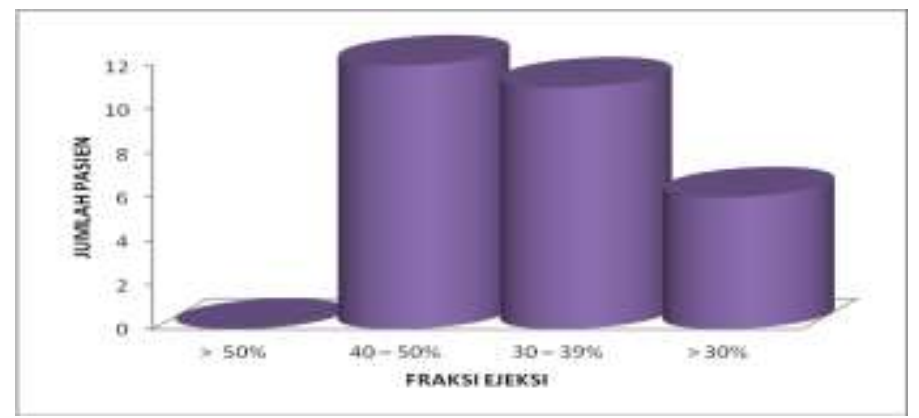

Gambar 4. Distribusi pasien gagal jantung kronik berdasarkan fraksi ejeksi

B. Penguji hipotesis pasien dengan gagal jantung kronik di Poliklinik Jantung BLU RSUP Prof. Dr. R. D. Kandou Manado Periode November - Desember 2012.

Tabel 6. Analisis hubungan antara NYHA kelas dengan Fraksi Ejeksi

\begin{tabular}{|l|c|c|c|c|}
\hline \multicolumn{1}{|c|}{$\begin{array}{c}\text { NYHA ( Fungsional / } \\
\text { Kelas ) }\end{array}$} & $<30 \%$ & $30-39 \%$ & $40-50 \%$ & $>50 \%$ \\
\hline & 1 & 1 & 2 & - \\
\hline NYHA I & 2 & 4 & 7 & - \\
\hline NYHA II & 3 & 6 & 2 & - \\
\hline NYHA III & - & 1 & 1 & - \\
\hline NYHA IV & 6 & 12 & 12 & - \\
\hline Total & $\mathrm{r}=0,175(\mathrm{p}=0,177)$ & & & \\
\hline
\end{tabular}


Hasil penelitian ini menggunakan uji Spearman diperoleh $r_{s}=-0,175$. Hasil ini menunjukkan bahwa secara statistik tidak terdapat hubungan bermakna antara kelas NYHA dengan fraksi ejeksi pada pasien gagal jantung kronik di BLU/RSUP Prof. Dr. R. D. Kandou Manado.

\section{BAHASAN}

Pada tahun 2012 dalam kurun waktu 2 bulan yaitu dari tanggal 1 November 2012 sampai dengan tanggal 31 desember 2012, ditemukan 860 total kunjungan pasien dengan diagnosa utama gagal jantung kronik pada instalasi rawat jalan RSUP Prof. Dr. R. D. Kandou Manado. Ditemukan pula 93 total perawatan untuk pasien dengan gagal jantung kronik yang dirawat di instalasi rawat inap RSUP Prof. Dr. R. D. Kandou Manado selama periode waktu tersebut. Dari bagian Poliklinik Jantung ditemukan 15 pasien yang memenuhi syarat untuk dianalisa sedangkan di Irina F Jantung ditemukan 15 pasien yang memenuhi syarat untuk dianalisa.

Pada penelitian ini ditemukan perbandingan yang jauh berbeda antara jumlah pasien laki-laki dan jumlah pasien perempuan, dengan persentase jumlah pasien laki-laki lebih banyak dibandingkan dengan jumlah pasien perempuan namun tidak signifikan, yaitu dari 30 kasus di RSUP Prof. Dr. R. D. Kandou Manado ditemukan 22 pasien (73\%) berjenis kelamin laki - laki dan 8 pasien (27\%) berjenis kelamin wanita. Hal ini mirip dengan hasil yang dilaporkan oleh Stromberg dan Martensson, dimana terdapat jumlah insiden gagal jantung tertinggi pada laki-laki. ${ }^{12}$

Menurut penelitian yang dilakukan MEDLINE dan CINAHL, penyakit gagal jantung kronik lebih sering dialami oleh laki - laki dibandingkan perempuan. Hal ini disebabkan karena pada umumnya laki laki lebih sering melakukan aktifitas fisik dibandingkan perempuan. Hal ini juga dipengaruhi oleh faktor gaya hidup, seperti merokok dan alkohol. ${ }^{13}$

Dari 30 kasus yang diteliti ditemukan 12 kasus (40\%) merupakan pasien dengan gagal jantung kronik berusia 60-69 tahun, kemudian disusul oleh kelompok umur 50-59 tahun dengan 11 kasus (37\%), kelompok umur 40-49 tahun dengan 4 kasus (13\%), dan yang paling sedikit adalah kelompok umur 30-39 tahun dengan 1 kasus (3\%). Hal ini mirip dengan statistik yang di publikasikan oleh Liyod-Jones dkk, dimana pada setiap peningkatan usia disertai dengan peningkatan jumlah penderita gagal jantung namun sedikit berbeda pada pendistribusian menurut jenis kelamin. ${ }^{14} \mathrm{Hal}$ ini kemungkinan berhubungan dengan faktor etiologi yang berbeda dimana di Indonesia prevalensi penyakit jantung rematik masih cukup tinggi.

Untuk menilai derajat gangguan kapasitas fungsional dari gagal jantung, pertama kali diperkenalkan oleh New York Heart Association (NYHA) tahun 1994. ${ }^{15}$ Pada penelitian ini ditemukan pasien yang datang berobat ke Poliklinik Jantung kebanyakan datang dengan kelas fungsional II atau sekitar 43\% dengan gejala berupa palpitasi dan dispnea timbul pada saat aktifitas fisik yang biasa. Hal serupa di dapat pada pasien yang menjalani perawatan di Irina F Jantung, namun berbeda dengan pasien baru yang akan menjalani perawatan, dimana kebanyakan pasien datang dengan kelas fungsional III atau sekitar 36\% dengan gejala berupa palpitasi dan dispnea timbul pada saat aktifitas fisik yang ringan.

Studi SOLVD, PROMISE, GESICA memakai batasan fraksi ejeksi < 35\% untuk gagal jantung yang berat (NYHA III-IV), namun ada juga studi yang memakai batasan fraksi ejeksi <40\% untuk yang berat. ${ }^{9-}$

${ }^{11}$ Pada hasil penelitian ini menunjukan bahwa secara statistik tidak terdapat hubungan bermakna antara kelas NYHA dengan fraksi ejeksi pada pasien gagal jantung kronik di BLU/RSUP Prof. Dr. R. D. Kandou Manado. Dimana, sebagian besar penderita terbanyak berada pada kelas NYHA fungsional II-III dengan fraksi ejeksi 30-39\% adalah 12 orang, sedangkan yang paling rendah terdapat pada NYHA III dengan fraksi ejeksi $<30 \%$ adalah 6 orang.

Tidak terdapat hubungan kelas NYHA dengan fraksi ejeksi dapat terjadi karena faktor peningkatan dan penurunan fraksi ejeksi yang tidak stabil yang dipengaruhi oleh faktor pemberian dan pemakaian dosis obat yang tidak optimal. Faktor lain yang dapat mempengaruhi kelas NYHA adalah usia, durasi gagal jantung, penyakit lain seperti gagal ginjal kronik dan angina pectoris, penggunaan diuretik, tekanan vena jugularis, edema ekstremitas bawah, dan kongesti paru. ${ }^{16}$ 
Pada penderita yang telah menggunakan penyekat EKA dan diuretik, aldosterone receptor antagonist spironolactone secara bermakna memperbaiki gejala- gejala gagal jantung, sehingga kelas NYHA menurun. ${ }^{16,17}$ Berbagai macam keadaan medis (tekanan darah, faktor komorbid), status fungsional, keadaan sosial (penikahan, status sosial), faktor ekonomi (askes, dan transportasi) dan psikososial (depresi dan kesehatan jiwa) juga menjadi salah satu faktor penyebab. ${ }^{17}$

\section{SIMPULAN}

Tidak terdapat hubungan yang signifikan antara kelas NYHA dengan fraksi ejeksi. Pasien gagal jantung kronik rawat jalan dan rawat inap di RSUP Prof. DR.R.D. Kandou Manado sebagian besar penderita terbanyak berada pada NYHA II-III dengan fraksi ejeksi 30-39 \% adalah 12 orang. Hasil penelitian menunjukkan bahwa setiap peningkatan usia akan disertai dengan peningkatan jumlah penderita gagal jantung namun sedikit berbeda pada pendistribusian menurut jenis kelamin.

\section{DAFTAR PUSTAKA}

1. Panggabean MM. Gagal Jantung. Dalam: Sudoyo AW, Setiyohadi B, Alwi I, Simadibrata M, Setiati S, editor. Buku Ajar Ilmu Penyakit Dalam. Edisi ke 5. Jakarta: InternaPublishing; 2009. hal. 1586.

2. Greenberg BH. The Medical Management of Chronic Heart Failure in Patients with Systolic Dysfunction. Hosenpud JD, Greenberg BH, editor. Congestive Heart Failure. Edisi ke 3. Philadelphia:Lippincott Williams and Wilkins; 2007. hal 621.

3. Squire I. Aetiology and epidemiology of chronic heart failure. Dalam: Kearney M. Chronic Heart Failure. New York: Oxford University Press; 2008. hal 2-4.

4. Gray HH, Dawkins KD, Simpson A, Morgan JM. Lecture Notes: Kardiologi. Edisi ke 4. Jakarta: Penerbit Erlangga; 2005

5. Schocken DD, Bejamin EJ, Fonarrow GC, Krumholz HM, Levy D, Mensah GA, dkk. Prevention of heart failure. Journal Of The American Heart Association. 2008;117:2544-65.

6. Fahri I. Evaluasi Ekokardiografi pada Gagal Jantung Diastolik. 23 Maret 2010 (16 Oktober 2012). Available from: http://www.kardiologi-ui.com/newsread.php?id=365

7. Baliga RR, Eagle KA. Heart failure Due to left Ventricular Systolic Dysfunction. Dalam: Dyke DB, Koelling TM, editor. Partical Cardiology. Edisi ke 2. Philadelphia: Lippincott Williams \& Wilkins; 2008. hal.256-7

8. Ingram RH, Braunwald E. Dispnea Dan Edema Paru. Dalam: Isselbacher KJ, Braunwald E, Wilson JD, Martin JB, Fauci AS, Kasper DL, editor. Harrison Prinsip-Prinsip Ilmu Penyakit Dalam. Volume 1.

9. Hunt S, Abraham T, Chin M et al. 2009 Focused Update Incorporated Into the ACC/AHA 2005 Guidelines for the Diagnosis and Management of Heart Failure in Adults: A Report of the American College of Cardioligy Foundation/ American Heart Association Task Force on Practise Guidelines Developed in Collaboration with the International Society for Heart and Lung Transplantation. J. Am. Coll. Card. 2009, 53; hal el-e90.

10. Moran A, Katz R, Smith N et al. Cystatin C Concentration as a Predictor of Systolic and Diastolic Heart Failure. J Card Fail 2008, 14. hal 19-26.

11. Carbajal E, Deedwania P. Congestive Heart Failure. Crawford M, editor. In Current Diagnosis and Treatment in Cardiology. McGraw-Hill, second edition, 2003. Hal: 217-47.

12. Stromberg A, Martensson J. Gender differences in patients with heart failure. Eur J Cardiovasc Nurs. 2003;2(1):7-18.

13. Stromberg A, Martensson J. Gender differences in patiens with heart failure. Department of Cardiology. Sweden: Eur J Cardiovasc Nurs: 2003;2(1):7-18. 
14. Lloyd-Jones D, Adams RJ, Brown TM, Carnethon M, Dai S, De Simone G, et al. Heart disease and stroke statistics - 2010 update: a report from the American Heart Association. Circulation. 2010; 121, e46-e215.

15. Manurung D. Gagal Jantung Akut. Dalam: Sudoyo AW, Setiyohadi B, Alwi I, Simadibrata M, Setiati S, editor. Buku Ajar Ilmu Penyakit Dalam. Edisi ke 5. Jakarta: InternaPublishing; 2009. hal. 1586.

16. Hauptman P, Kaya MW, Heidenreich PA, Chin M, Edwards ML, Dunlap Met al, Klinik of heart failure: pernyataan konsesus. HFSA. 2008:14;10-3.

17. Ahmed A, Aronow WS, Fleg JL. Higher New York Heart Association Classes and Increased Mortality and Hospitalization in Heart Failure Patients with Preserved Left Ventricular Function. Am Heart J: 2006 ;151(2):444-450.

18. Idler EL, Kasl SV, Lemke JH. Self-evaluated health and mortality among the elderly in New Haven, Connecticut, and Iowa and Washington counties, Iowa, 1982-1986. Am J Epidemiol 1990;131:91-103. 